\title{
IMPACT OF PRODUCT DEVELOPMENT AND INNOVATION ON ORGANISATIONAL PERFORMANCE
}

\section{UDEGBE Scholastica E. ${ }^{1}$--- UDEGBE Maurice I. $^{2}$}

'Lecturer, Lagos state University, Faculty of Management Sciences, Department of Business Administration and Management Technology, Marketing Program.

${ }^{\circ}$ Member - Institute of Strategic Management of Nigeria

\begin{abstract}
In today's global market, businesses are faced with intensive competition and in order to obtain a sustainable competitive advantage, they have to adopt processes and system for development of their new products, as well as the improvement of the existing products through innovation. This study was designed to investigate the relationship between organizational performance and product development by innovation. The data was collected from the marketing managers, operation managers and those managers who have been involving greatly in product development and innovation process. A total of 185 useable questionnaires were completed though research sample of 120 firms in Nigeria. The result of the study were interpreted using Likert model and SPSS package for the analysis of some appropriate statistical methods such as factor analysis, regression, and reliability analysis. The findings show that the impact of product development on organizational performance was higher in Nigeria when consumers perceive product innovation as stronger, more favorable and more unique. Creativity/quality of the innovation process exert a positive influence on product development and organizational performance. To literature, the study has supported previous studies on product development and performance especially in developing economies such as Nigeria, Malaysia, Ghana, and among others. Therefore, it was recommended that creative/quality innovations should be maintained continuously to develop appropriate product continually.
\end{abstract}

Keywords: Product, Development, Innovation, Organization, Performance.

Received: 24 October 2013/ Revised: 11 November 2013/ Accepted: 15 November 2013/ Published: 19 November 2013

\section{INTRODUCTION}

Product development and innovation is a crucial business consideration for today's turbulent dynamic environment. For organization's success, continuous innovation and effective product 
development become requirement for all organizations. As a result, innovation, product development among others has been a frequently survey topic over the last few decades. Innovation is a process of developing some principles for managing new product development while a product is something that is sold by an organization to its customers. It can be referred to as goods (physical, tangible products) or services (intangible products). Product development is the set of activities beginning with perception of a market opportunity and ending with production, sale and delivery of a product (Ulrich and Eppinger, 2007). Product development demands the integration of many actors of different knowledge and expertise in order to develop a high technological product (Chux Gervse Iwe, 2010). There are a number of remarkable studies that emphasized product development innovation, and performance, relationship (Zirger et al., 1990; Drucker, 1997; ImS and Workman, 2004; Wei and Morgan, 2004; Yannele, 2005), Wheelwright and Clark (1992), Page (1993) among others, they found a strong support for the basic proposition that product development and innovation influence the overall performance of an organization. However, this field of study has received less attention by academic researchers in developing economies such as Nigeria. This paper aims to investigate the relationship between product development, innovation and organizational performance in Nigeria. The role of product quality and profitability in an organization, and the relationship between product development and improvement of market share are also considered. Thus, this study will be beneficial to producers because it is a guide towards understanding the importance of innovation in creating a product that are capable of facing competition in a dynamic environment. It will also give a firm's product the opportunity to remain in the growth stage for as long as possible, knowing fully well that business environment is highly dynamic, and the success of any business must revolve round innovative ability for successful product development that will create a market for a firms product. On the part of consumer, satisfaction will be easily guaranteed from the goods they consume or intend to buy, Product will always be developed with the drive to meet their needs and wants. Consumer satisfaction will lead to customers' loyalty and in turn result to more sales and revenue for the producing firm/organization. In the light of the above, this study is undertaken to examine the probable relationship between product development, innovation and organizational performance in Nigeria.

\section{LITERATURE REVIEW}

The success of any organization can be traced or linked with successful products and this depends on their ability to identify the needs of customers and to quickly create products that meet these needs. Therefore, product development can be described as the life blood of any business organization Brown and Eisenhardt (1995), Balbutin et al. (2000), Efcharis et al. (2008), Chux Gervse Iwe (2010). Satisfying the needs of customers is not solely a marketing problem, nor is it solely a design problem or manufacturing problem. It is a product development problem. Product development is an interdisciplinary activity that requires contributions from nearly all 
the functions of a firm, however three functions are almost central to a product development effort. These include marketing, design and manufacturing (Ulrich and Steven Eppinger, 1995; Ulrich and Eppinger, 2007). The marketing function mediates interactions between the firm and its customers. Marketing often facilitates the identification of customer needs. Marketing also typically arranges for communication between the firm and its customers, set prices, and overseas the launch and promotion of the product (Ulrich and Eppinger, 2007) The design function leads the definition of the physical form of the product to best meet customers' needs. The design function could be engineering, industrial, promotional or all of the above, (Ulrich and Steven Eppinger, 1995). The manufacturing function is primarily responsible for designing and operating the production system in order to produce the product. Broadly defined, the manufacturing function also includes purchasing, distribution and installation (Ulrich and Eppinger, 2007). Product development means offering new or improved product for present markets. By knowing the present markets needs, a firm may observe ways to add or modify product features, create several quality levels, or add more types or sizes by introducing new versions of popular programmes, i.e. attributes of innovations.

An innovation is defined as an idea or object that is perceived as new by an individual or an agency . "The perceived newness of the idea from the individual's point of view determines his or her reaction to it. If the idea seems new to the individual, it is an innovation (Robertson and Tu, 2001). An innovation consists of certain technical knowledge about how the things can be done better than existing state of the art. The innovativeness of a new product and firm innovation capability is important for several reasons. Innovation products present opportunities for firms in terms of growth and expansions into new areas as well as allows firms to gain competitive advantage, innovation by itself is defined as the generation, acceptance, and implementation of new ideas, processes, products or better services. The innovation process includes the acquisition, dissemination and use of new knowledge (Calantone et al., 2002) and successful implementation of creative ideas within an organization (Amabile et al., 1996).

Product development and innovative drive provides organization enabling environment to achieve a higher level of performance and better customer values. Liu et al. (2002). Researchers have also concluded that organizational learning is associated with development of new knowledge, which in turn is crucial for firm innovativeness and firm performance (Liu et al., 2002).

Significant innovations allow firms to establish dominant competitive positions, and afford new comer firms an opportunity to gain an edge in the market. Firm innovativeness consists of different dimensions, product innovativeness examined in the literature both from customers perspective and firms perspective; innovation in product process, work organization and human resource management practices. A product or a process orientation of firm innovativeness will result in success if the firm undertakes actions valued by the market. According to Petrella (1996) developing great products is hard. Few companies are highly successful more than half the time and this is a significant challenge for a product development team. Some of the 
characteristics that make product development challenging are:- tradeoffs, dynamics, details, time pressure, and creation. Others include satisfaction of societal and individual needs, team diversity and team spirit. Trade-offs deals with making choice between product specification and the impact of cost around the choice. Customer preference, competition the environment and technology are all dynamic variables. These pose serious challenges to a product development effort. Product development decisions must usually be made quickly considering the fact that products are meant to satisfy the needs of some kind. It is also necessary to understand that where product development is concerned, all hands must be on deck and that the teams work with one spirit (Sethi, 2000).

\section{CONCEPTUAL FRAMEWORK AND DEVELOPMENT OF HYPOTHESES}

The major variables of this study were product development and innovation (independent variable), and organizational performance (dependent variable). Figure I. product development is denoted by (PD), innovation is denoted by (IN), and organizational performance is symbolized by $(\mathrm{OP})$. The focus of this study was organizations in Nigeria (manufacturing and servicing firms) which in recent years has been characterized by many innovative products in the forms of variation in quality, designs and sizes. Generally, researcher look at product development in terms of product lines and product size.

Figure- 1. The relationship between product development, product innovation and organizational performance

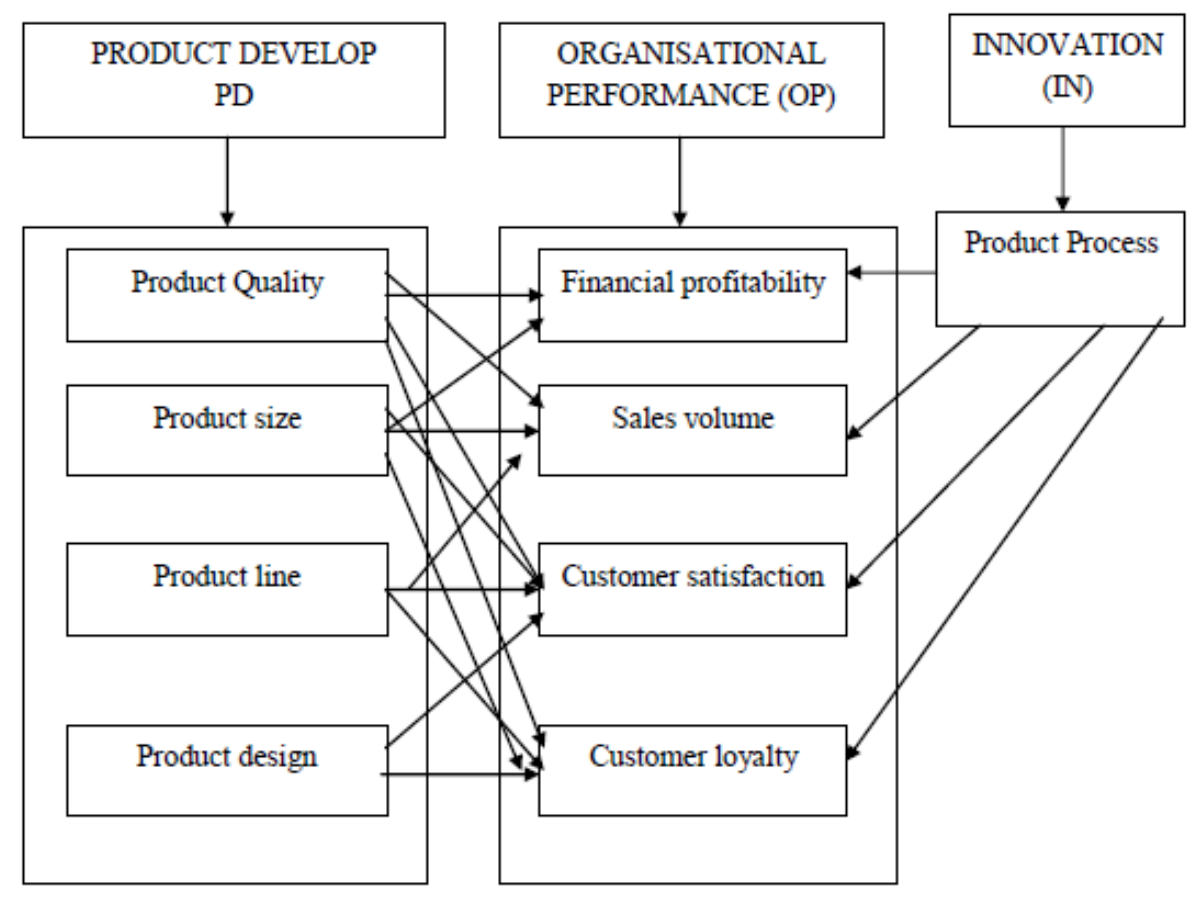

Source: (Survey study) 
However product quality will be considered for the purpose of this research. Innovation is seen in form, and innovation, in product process. It should be emphasized at this juncture that there are other criteria or variable that may be used to measure product development and product innovation.

Organizational performance in this study is measured in terms of profitability, sales volume, market share, customer satisfaction and customer loyalty.

Thus we hypothesize the following

$\mathrm{H} 1$ - the impact of product development on organizational performance tend to be higher when consumers' perception on product innovation is stronger, more favorable and more unique than when it is low.

$\mathrm{H} 2$ - the impact of product development on organizational performance tends to be higher when creativity/quality of the innovation process is high than when it is low.

H3 - product development by creative innovation would exert a positive influence on organizational performance.

\section{RESEARCH METHOD}

\subsection{Questionnaire and Measures}

The questionnaire included two parts the first part measured product development and product innovation, product quality, profitability, sales volume, market share, customer satisfaction, customer loyalty and organizational performance. The second part recorded respondent demographic information:- gender, marital status, age levels, education, occupation, income level.

1. The present research uses a cross-sectional study design which aims to test the relationship between product development and product innovation (independent variable) and organizational performance (dependent variable). Cross sectional design involves the connection of information from any given sample of population element only once. This design is suitable for studies that aimed to analyze a phenomenon, situation, problem, attitude or issue by considering a cross section of the population at one point in time. The advantage of this method is that it is cheaper, less time consuming than a longitudinal design. In fact, the majority of extant literature on product development, innovation and organizational performance studies (e.g. Vourlioti et al. (2008), Nwokah et al. (2009), have employed cross-section designed. Furthermore, hypothesis testing is implemented to explain the variance to the dependent variable. This study also employed the survey method, which makes use of a questionnaire. The researcher used self administered questionnaire as a means of data collection. The self administered questionnaire was handed out to all the respondents and collected back after they have been completed. Self administered questionnaire was chosen for several reasons. This method is cheaper to administer quicker to administer, absence of interviewer effects, no 
interviewers variability and convenience for respondents (Bryman and Bell, 2007). Product development, product innovation and organizational performance Cronbach alpha measured $=82$, (p.86 and p.88). The five points Likert scales are used to indicate the degree of agreement or disagreement from the respondents (Zikmund, 1997). It ranges from strongly agree to strongly disagree. The close ended question and the open ended question are applied together. A pilot study of the questionnaire was conducted to evaluate the content validity. Content validity was assessed by a group of experts who decide whether the test represents all of the contents of a particular construct. After evaluation by six academics and three local professionals in this field, some items were reworded based on their feedback. The number of questionnaires distributed is 260 with response rate of $71.2 \%$ (i.e. 185 useable questionnaire)

The reliability of constructs was tested by using Cronbach's coefficient alpha, which range from 0.82 to 0.88 , much larger than the standard of 0.7 (Churchill, 1979). Since all measures were based upon prior relevant literature and were often used or adapted in research, evidence of content validity was also provided. Next, measures of product development, product innovation and organizational performance were subjected to a confirmatory factor analysis (CFA) through the use of AMOS 5.0. The CFA allows for a validity assessment of the measures used.

The fit indices $\left(\mathrm{X}^{2} / \mathrm{df}=1.62, \mathrm{p}=0.000\right.$, goodness - of - fit index $(\mathrm{GFI})=0.81$

Adjusted goodness-of-fit index $(\mathrm{AGFI})=0.85$

Confirmatory fit index $(\mathrm{CFI})=0.90$

Normed fit index $(\mathrm{NFI})=0.88$, root - mean square error of approximation

(RMSEA $)=0.07$. This suggests a good fit of measurement model on the whole and the development of hypothesis, conceptually and theoretically is said to be supported by empirical data. Discriminant validity was tested. Discriminant validity is the extent to which the measures of conceptually

Table- 1.Results of factor analysis for discriminant validity

\begin{tabular}{lccccc}
\hline Variable & Factor1 & Factor2 & Factor3 & Factor4 & Factor5 \\
\hline Product development & 0.832 & & & & \\
\hline Product innovation & 0.879 & & & & \\
\hline Product quality & 0.812 & & & & \\
\hline Customer satisfaction & & 0.782 & & & \\
\hline Sales volume & & & 0.814 & & 0.856 \\
\hline Market share & & & 0.841 & \\
\hline Customer loyalty & & & & 0.929 \\
\hline Profitability & & & & & \\
\hline Organizational performance & & & & \\
\hline
\end{tabular}

Note: percentage of total variance explained $84.8 \%$

Distinct constructs differ. To test validity, a simple factor analysis was conducted using the principal to test discriminate validity we conducted a simple factor analysis using the principal 
component method to measure product development, product innovation and organizational performance (table 1). Result indicated that five factors emerged, which could explain more than $84.8 \%$ of total variance. Factor loading were all above 0.5 on the corresponding constructs, reflecting that our respondents could discriminate among the measures of product development, product innovation, product quality, product satisfaction, product loyalty and organizational performance, hence offering evidence of discriminate validity (Podsakoff and Organ, 1986).

The sample frame consisted of marketing managers, operation managers, and those managers who have been involving greatly in product development and product innovation process in Nigerian manufacturing and services firms located in Lagos state of Nigeria. The sample respondents were gotten using convenience sampling method. These city (Lagos) enjoy a higher per capital income and a better standard of living than other cities in Nigeria, therefore, there are more potential buyers and sellers of innovative products and new product development in these location.

Finally, 185 useable questionnaire with a response rate $71.2 \%$ were collected. There were 96 females $(51.9 \%)$ and 89 male respondents (48.1\%). A majority of the respondents were older than 3oyrs $(74.6 \%)$. Most of the respondents had university education or higher diploma education (72.0\%). Their careers mainly fell into marketing/business, production and research. Most respondents had a personal monthly income of more the $\$ 2,288$ (\$350,000.00).

\section{RESULTS}

The correlation coefficients among the five investigated constructed were in the range of 0.38 and 0.49 and were all statistically significant at the $\mathrm{p}<.01$ level, showing a positive correlation pattern among variables. Next, regression analyses were conducted to test the hypotheses, after controlling for gender, age, educational level, monthly income and career. The descriptive control variables were categorical and entered as dummy variables. Result show that none of the control variables was found significant in affecting organizational performance. Finally six regression models were developed (table not shown). Product /quality were fund to significantly impact organizational performance with a positive standardize coefficient of 0.39 (table not shown)

Result also revealed that all the variance inflation factors (VIFs) of the independent variables were between 4 and 6 , lower than the standard of 10 (Marsh et al., 2004).

H3 hypothesized that product development by creative innovation would exert a positive influence on organizational performance. Based upon the regression analysis result, the $\mathrm{R}^{2}$ change for product development is $8 \%$ and is statistically significant at the $\mathrm{p}<.001$ level; a positive standardized regression coefficient is associated with organizational performance (0.42) hence supporting $\mathrm{H} 3$

$\mathrm{H} 1$ predicted that the impact of product development on organizational performance would be higher when consumers perception on product innovation is stronger, more favorably and more unique was high than when it was low. According to the regression analysis result (not 
shown), the $\mathrm{R}^{2}$ change for the impact between product development and product innovation is $4 \%$ with a standardized regression coefficient of 0.38 ( $\mathrm{p}<.001)$, thus supporting $\mathrm{H} 2$ figure illustrate the product development by product innovation influence organizational performance.

$\mathrm{H} 2$ predicted that the impact of product development on organizational performance would to be higher when the creativity quality of the innovation process is high than when it is low.

$\mathrm{H} 2$ is actually based on the creativity/ quality of the innovation process. According to the regression analysis (not shown) the $\mathrm{R}^{2}$ change is $4 \%$ which is statistically significant at the $\mathrm{p}<.001$ levels, and the standardized regression coefficient is 0.32 , showing that, in product development, when the creativity/quality of the innovation process is high, there is significant positive impact on organizational performance. Process acts as a positive moderator between product development and organizational performance. Thus $\mathrm{H} 2$ is statistically supported.

\section{DISCUSSION}

The study has focused on the in-dept analysis of impact of product development and innovation, on organizational performance specifically in Nigeria firms. Results reveal that product development by creative/quality innovation significantly and positively impact organizational performance. Consumer perception on the product innovation as stronger, more favorable and more unique are found to be important moderators in the relationship between product development by innovation and organizational performance. These findings offer new perspectives concerning research in developing economies and also provide insightful managerial implications. Importantly, this study was conducted in Nigeria, a major representative of developing economies. Very few studies in this regard had been conducted in non developed settings, hence, with successful replications, findings might be generalized to other developing countries or areas. (Robertson and Tu, 2001; Liu et al., 2002)

Product creativity/quality of innovation is found to positively affect consumers perception and likewise the purchase intentions, the profitability, volume, customers satisfaction, customer loyalty, and thus, the organizational performance, this is in line with prior results in extent literature, such as (Zirger et al., 1990; Wei and Morgan, 2004) among others.

\subsection{Managerial Implications}

This study also provides several important managerial implications for firms in Nigeria. The general implication is that while it necessity for product development to take place, in order to meet the needs and wants of consumers, companies must strive to achieve and creative \& quality product innovations that consumer perceive as stronger, more favorable and more unique for the product development, so as to differentiate themselves from the various similar products in the market. 
Likewise, from a managerial perspective, it can be concluded that the essence of product development and innovation is to build up customer product satisfaction, attractiveness and thus customer loyalty. Companies need to examine their own strength and weaknesses in terms of these three elements (i.e. customer satisfaction, customer attractiveness and customer loyalty find select appropriate strategies by which they can create competitive advantages regarding product development and innovations.

Furthermore, product creativity/quality plays a moderating role between product development and organizational performance. Thus indicate that, to achieve success, organizations, need to make their products innovation highly prominent, stronger, more favorable and more unique in customer minds in order to experience the positive effect of product development on organizational performance.

Finally, as globalization grows and competition intensifies in developing economies, it is essential for multinational companies to understand local consumers' perceptions about their level of innovations and product development. Multinational companies should also be aware of the level of customers satisfaction derived from local products and also the level customer loyalty. Although managers may exert considerable effort, gaining accurate local marketing knowledge of the level of product development innovation, customer satisfaction and loyalty level remain a huge challenge for any multinational in developing economies. Thus, multinationals may increase their knowledge on the product development and innovation process, from the local level, and thus help by setting clear organizational goals.

\subsection{Limitation and Future Research}

The first limitation of this research has to do with the study itself. It did not include product size, product lines and product design as independent variables for product development, and these may be potential factors influencing organizational performance. it is desirable for future research to consider the above variables.

Finally, we recognize that this research has to do with the sample size that is considered as relatively small (185 respondents). Another concern is that the research sample includes heterogeneous companies from various sectors. Therefore, a similar study could be applied to bigger and more representative and specific sample.

Funding: This study received no specific financial support.

Competing Interests: The authors declare that they have no competing interests.

Contributors/Acknowledgement: All authors contributed equally to the conception and design of the study.

\section{REFERENCES}

Amabile, T.M., R. Conti, H. Coon and J.h. Lazenby, M., 1996. Assessing the work environment for creativity. Academy of Management Journal, 39(5): 1154-1184. 
Azaze - Azizi Abdul, A. and J. Evelyn, 2010. Market orientation and new product performance: The mediating role of product advantage. African Journal of Marketing Management, 2(5): 100.

Balbontin, A., Yazdani, B. B., Cooper, R. and Souder, W.E., 2000. New product development practices in Amerkan and British firms. Technovation, 20(5): 257-274.

Brown, S. and K. Eisenhardt, 1995. Product development: Past research present finding and future directions. Academy of Management Review, 20(2): 343-378.

Bryman, A. and E. Bell, 2007. Business research methods. New York: Oxford University Press.

Churchill, G.A.J., 1979. Paradigm for developing better measures of marketing constructs. Journal of Marketing Research, 16(February): 64-73.

Chux Gervse Iwe, 2010. Impact of product development and innovation on market share. African Journal of Business Management, 4(13): 2659-2667.

Drucker, R., 1997. Beyond market orientation, knowledge management and the innovativeness of New Zealand firms. USA Emerald Group Publishing Ltd, 5(24): 582.

Efcharis, S.V., D.C. Prodromos and D.D. Anastasios, 2008. New product development process and its impact on product quality MIBES Transactions, 2(1): 190-201.

ImS and J. Workman, 2004. Market orientation, creativity and new product performance in high technology times. J. Mark, 68(2): 114-132.

Marsh, H.W., M. Dowson, I. Pietsch and R. Walker, 2004. Why multincollinearity matters: Are examination of relations between self efficacy, self concept, and achievement. Journal of Educational Psychology, 96(3): 518-512.

Nistish, G., P. Hitendra Bergal Manish, Bhanusavena, Y. Santosh Kumar, S. Rajeev, 2010. Impact of innovation on new product development in India, University of Kelanya, Sri Lanka.

Nwokah, N.G., E.I. Ugoji and J.N. Ofoegbu, 2009. Product development and organizational performance. African Journal of Marketing Management, 1(3): 89-101.

Ohanian, R., 1990. Construction and validation of a scale to measure celebrity endorsers perceived expertise, trustworthiness, and attractiveness. Journal as Advertising, 19(3): 39-52.

Page, A.K., 1993. Assessing new product development practices and performances: Establishing crucial norms. Journal of Product Innovation Amanagement, 10(4): 273-290.

Petrella, R., 1996. Globalisation and international: The dynamics of the emerging world order. In R. Boyer and D. Drache (eds) state against markets Routledge, London.

Podsakoff, P.M. and D.W. Organ, 1986. Self reports in organizational research: Problems and prospects. Journal of Management, 12(4): 531-544.

Robertson, P.L .and Tony .F. Tu, 2001. Firm strategy, innovation and consumer demand: A market process approach. Managerial and Decision Economics, 22(4-5): 183-199.

Roger, J. Calantone, Tamer Cavusgil S. and Yushan Zhao, 2002. Learning orientation, firm innovation capability and firm performance. Industrial Marketing Management, 31 (6): 515-524. 
Sandra, S.Liu, Xueming Luo, and Yi- Zheng Shi, 2002. Integrating customer orientation, corporate entrepreneurship, and learning orientation in organizations - in transition: An empirical study. International Journals Research in Marketing, 19(4): 367-382.

Sethi, R., 2000. New product quality and product development teams. J. Mark, 64(2): 1-14.

Ulrich, K. and S. Eppinger, 2007. Product design and development. 4th Edn., New York: McGraw Hill.

Ulrich, K.T. and D. Steven Eppinger, 1995. Product design and development. New York: McGraw - Hill.

Vourlioti, E.S., P.D. Chatzoglou and A.D. Diamantidids, 2008. New product development process and its impact on product quality MIBES Transactions, 2(1): 190-201.

Wheelwright, S.C. and K.B. Clark, 1992. Revolutionizing product development The Free Press, New York.

Yannele, W. T., 2005. Marketing theory principles and practices, London, Macmillan Books Ltd. pp: 92.

Yinghong (Susan), Wei and Neil A. Morgan, 2004. Supportiveness of organizational climate, market orientation, and new product performance in Chinese firms, Journal of ProductInnovation Management, $21(6):$ 375-388

Zikmund, G.W., 1997. Business research methods. 5th Edn., Florida: The Dryden press.

Zirger, J. Billie, Maidique and Modesto, 1990. A model of new product development: An empirical test. Manage Sci., 36(7): 867-881.

\section{Biography of the Authors}

1. UDEGBE ScholasticaEbarefimia - Lecturer with Lagos State University, Faculty of Management Sciences, Department of Business Administration and Management Technology, Marketing Program.

Ph.D Business Administration, from Lagos State University. Nigeria.

Ph.D Geography and Regional Planning (Agricultural Geography) from Ambrose Alli University, Nigeria.

M.Sc. Business Administration (Marketing) and B.Sc Business Administration - both from University of Lagos. Nigeria.

Fellow of National Institute of Marketing of Nigeria.

Member - Institute of Strategic Management of Nigeria.

Email: scholasticudegbe@yahoo.co.uk

2. UDEGBE Maurice Inedegbor - B.Sc. (Accounting) - from Ambrose Alli University, Nigeria.

M.Sc Business Administration - Lagos State University, Nigeria. Principal consultant - Myke Pee Associate, Lagos, Nigeria. Member - Institute of Strategic Management of Nigeria.

Email: maurice.udegbe@yahoo.co.uk 